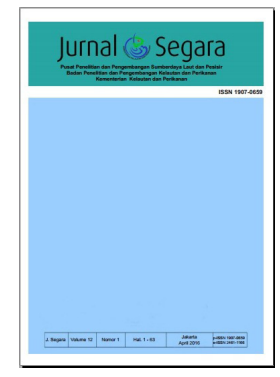

\title{
JURNAL SEGARA
}

http://p3sdlp.litbang.kkp.go.id/segara

ISSN : 1907-0659

e-ISSN : 2461-1166

Accreditation Number: 559/AU2/P2MI-LIPI/09/2013

\section{SALINITY STRUCTURE WITHIN THE ESTUARY OF BINTUNI BAY, AT THE SOUTHERN PART OF BIRD HEAD OF WEST PAPUA, INDONESIA}

\author{
( Wayan Nurjaya') \\ ${ }^{1)}$ Laboratorium Oseanografi Dept. ITK-FPIK-IPB Marine Center Building Lt. 3, Kampus IPB Darmaga, Bogor 16680
}

Received: 1 August 2016; Revised: 10 August 2016; Accepted: 15 August 2016

\begin{abstract}
Bintuni Bay is a semi-closed bay which a lot of big rivers flow into the bay and bring a huge amount of freshwater. This bay is not directly connected to the open sea but separated by the Berau Bay. The bay of Berau has wider bay mouth as well as deeper than Bintuni Bay, the deepest part more than $70 \mathrm{~m}$ located at the center part of bay. Tidal force generated offshore is able to push higher salinity water (HSW) mass further into the inner bay, otherwise the low salinity water (LSW) mass pushed out toward the head of the bay. In the area where LSW and HSW masses meet each other is found steep salinity gradient (salinity front). Two times field observations were conducted with lowered CTD (Conductivity Temperature Depth) sensor from the surface layer until one meter above seabed at 30 stations, either at the end of north-east monsoon (March 2013) or at south-east monsoon (July-August 2013). The HSW mass was dominant found at deeper layer and southern side of the bay, while the LSW mass occupied surface layer at the northern side of the bay.
\end{abstract}

Keywords: salinity front, high salinity water, low salinity water, Bintuni Bay, Berau Bay

\section{INTRODUCTION}

As an archipelago country, Indonesia possess more than 17 thousands islands, not only consisted of small islands but also consisted of five big islands (Papua, Kalimantan or Borneo, Sumatera, Java, and Sulawesi or Celebes). Within all those big islands are found several big rivers flowing into the coastal seas. For example, Musi River and Batanghari River in Sumatera; Citarum River, Citandui River and Bengawan Solo River in Java; Mahakam River and Kapuas River in Kalimantan as well as Digul and Mambromo Rivers in Papua. Surely, other big rivers are not entirely mentioned here.

Well known that main function of the river and estuary is as water tranportation and also as livelyhood for fisherman (potential area for fishing ground, nurshery ground and feeding ground). For that reason since few centuries ago mostly fisherman and other society live at the river bank and in the coast of estuary. Goldberg (1994) said that more than 50\% world population living in $1 \mathrm{~km}$ of coastal zone. The population might be increased around $1.5 \%$ within next ten years. Estuary has also high nutrient content (French, 1997) so it has high productivity and provides food for many kind of fishes (feeding ground), as well as for growth (nursery ground). Generally, sediment concentration structure either vertically or horizontally, as well as erosion, suspension and deposition in estuary depends on sediment type, tidal current and water depth (Prandle, 2004).

Estuary is one of terminologies used in oceanography decipline where water mass flow from the river mixed with water mass from the ocean, so formed salinity gradient (vertically or horizontally) from the mouth to the head of estuary, on the contrary. Mixing type of water mass within estuary depends on estuarine depth, opening of the estuary's mouth, fresh water volume flow into the estuary and tidal range (Dyer, 1973; Liu et al., 2008).

Related researches of estuary in Indonesia are very rare (Mandang \& Yanagi, 2008). On the contrary, they are found several interesting phenomena within the estuary, such as in physical aspects are salinity front, water mass startification, mixing and stirring due to tidal forces as well as other biogeochemical processes. On this paper spatial and temporal salinity

Corresponding author:

Jl. Pasir Putih I Ancol Timur, Jakarta Utara 14430. Email: i.wayan.nurjaya@ipb.ac.id 
structure as an indicator water mass dynamics processes in estuary will be described. The objective of this study is to mapping salinity structure within the Bintuni Bay on two differences seasons, there are northeast monsoon and southeast monsoon.

\section{METHODOLOGY}

\section{Location and time}

The study was conducted at the Bintuni Bay located at the southern part of the head bird of West Papua (Figure 1). Field observation was conducted on two different seasons. First observation in March as representative of northeast monsoon and the second observation in July as representative of southeast monsoon).

\section{Data Collection}

Data and information are used on this study collected from few resources, prime data are originated from two times field observations and other supporting data gained from the previously studies. Several parameters measured on the field observation in March 2013 were water temperature, salinity and current. Field measurements were conducted at 30 CTD (Conductivity Temperature Depth) stations as described in Figure 1. CTD sensors were slowly lowered down until close to the seabed. Current was measured at several depth layers $(2 \mathrm{~m}, 10 \mathrm{~m}, 20 \mathrm{~m}, 30 \mathrm{~m}$ and 40 m depending on water depth of each station).

Based on field observation water circulation within the Bintuni Bay is dominated by tidal current. In order to understand the dynamics of water mass within the bay then simulation was conducted by using the MIKE 21 FM application. Data used as an input model are bathymetry, tidal and wind condition. Model result is validated by field measurement data collected from mooring data recorded at the Ocean Tower site located at the middle of the bay.

\section{Data Analyses}

Water temperature, salinity and pressure (from depth) data recorded from CTD sensors are used to calculate water density, then it is plotted into profile and section forms by ODV (Ocean Data View) Ver. 4.5.6.

The pattern of water circulation within the bay was calculated and simulated based on momentum equation and it was running during a period of 15 days. Four points of water level positions were picked up to know the circulation pattern at those points. There are when water level at the mean sea level move to the highest point of flood time, water level at the highest point of flood time, at mean sea level when move down to lowest point during the ebb time, and water level at the lowest point of ebb time.
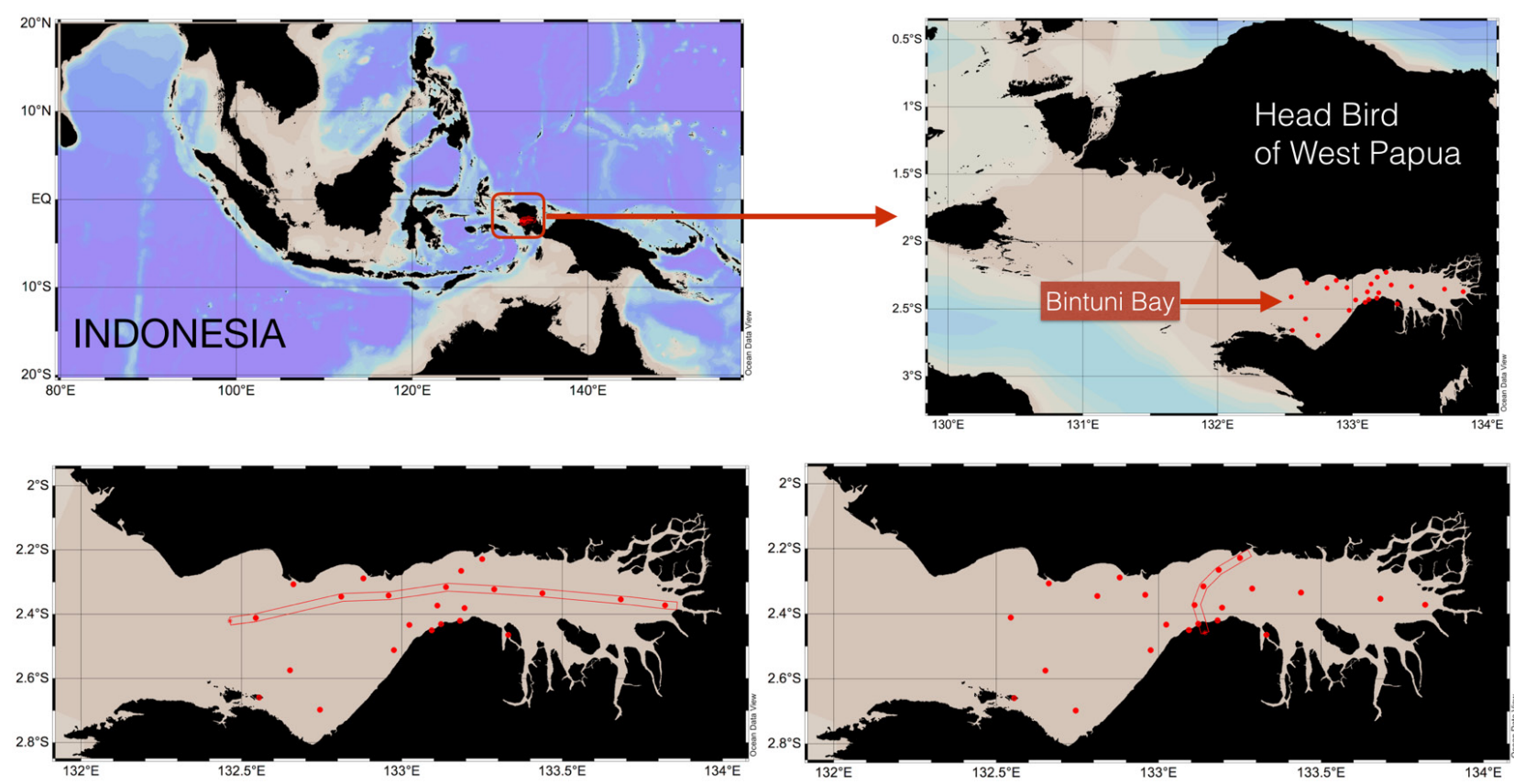

Figure 1. Study area and CTD stations indicated bay the red dots (the top-right panel), across along bay transect line (from the mouth to the head bay in left bottom panel), and red transect line cross the bay from north to south of the bay (right bottom panel). 


\section{RESULT AND DISCUSSION}

Bintuni Bay and Berau Bay are adjacent each other. The Bay of Berau is located at outer part, otherwise Bintuni Bay is located at the inner of the bay. Both bays are located at southern part of the head bird of West Papua. Generally, the bays have morphology as horn, wide shape at the mouth of bay and narrow shape at the head of bay. The bay is elongated eastwest direction with total length of $160 \mathrm{~km}$. The mouth of bay is opened to offshore ward of east Halmahera Sea directly connected to the Pacific Ocean. The most widely part of the bay is $50 \mathrm{~km}$ located at the mouth of Berau Bay. Several big rivers flow into the bay causing the low salinity water form mainly in surface layer around of river mouths.

Depth of Bintuni Bay is varied from a view meters $(<5 \mathrm{~m})$ along the bay coast, until more than $70 \mathrm{~m}$ depth in the middle part of the bay and closed to bay mouth. The detail description of water depth can be seen in Figure 2. Water depth in the center part of the bay can reach $>50 \mathrm{~m}$ depth. The deepest part the bay reaches the distance of $125 \mathrm{~km}$ from mouth bay. At close to the head bay the water depth gradually becomes shallow from $15 \mathrm{~m}$ and finally is closed to shoreline water depth $<2 \mathrm{~m}$. It can also be changed depending on the tidal condition.
Long period measurement of sea level fluctuation was conducted at Tanah Merah, from admiralty analysis the tidal component values are able to calculate (Table 1). From the main component of tidal finally Formzhal Number was calculated. It is 0.6 means that tidal type occurred in Bintuni Bay is mixed tide prevailing semidiurnal (ebb and flood tend to be twice a day).

Sea level fluctuation was also measured during one month period at Ocean Tower Station, measurement result is ploted as fluction line according to time (Figure 3 ). Tidal ranges reached $4 \mathrm{~m}$ at spring tide and only $1.2-2.0 \mathrm{~m}$ on neap tide period.

Current measurement via mooring of current meters (CM) conducted at two layer depths (at $5.5 \mathrm{~m}$ depth and $0.5 \mathrm{~m}$ depth onto the sea bed) is plotted in Figure 4. Generally, major current direction in two different layers is northeast-southwest direction. The strongest current speed at $5.5 \mathrm{~m}$ depth from seabed in major direction was $74.4 \mathrm{~m} / \mathrm{s}$, otherwise in minor direction only $5.0 \mathrm{~m} / \mathrm{s}$. At depth layer of $0.5 \mathrm{~m}$ from the seabed, major and minor current directions were 46.0 $\mathrm{cm} / \mathrm{s}$ and $6.1 \mathrm{~cm} / \mathrm{s}$, successively.

Model results are described in Figure 5 . Simulation was running at each monsoon and each monsoon picked it up at four different water level

Table 1.

Tidal Component at Bintuni Bay (BP Tangguh, 2002)

\begin{tabular}{|c|c|c|c|c|c|c|c|c|c|c|c|}
\hline S2 & N2 & K2 & K1 & O1 & $\mathrm{P} 1$ & M4 & MS4 & Zo & $\mathrm{F}$ & & \\
\hline Amplitude (m) & 0.89 & 0.27 & 0.20 & - & 0.45 & 0.27 & 0 & 0.03 & 0.02 & 2.15 & 0.62 \\
\hline Phase (degree) & 179 & 272 & 125 & - & 347 & 313 & 348 & 322 & 58 & - & - \\
\hline
\end{tabular}

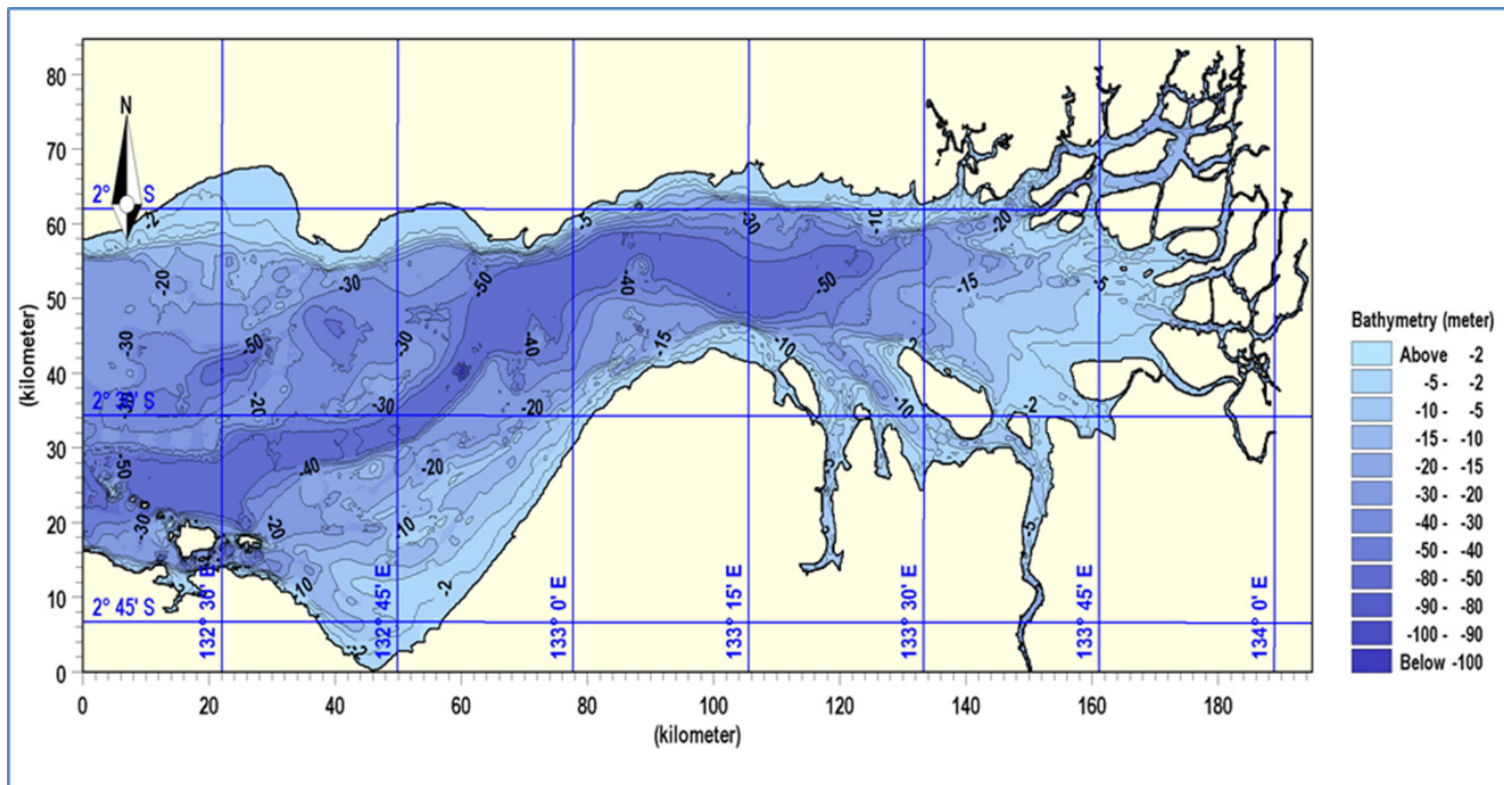

Figure 2.

Bathymetry condition of Berau and Bintuni Bays, color bar in right panel indicated water depth in meter. 


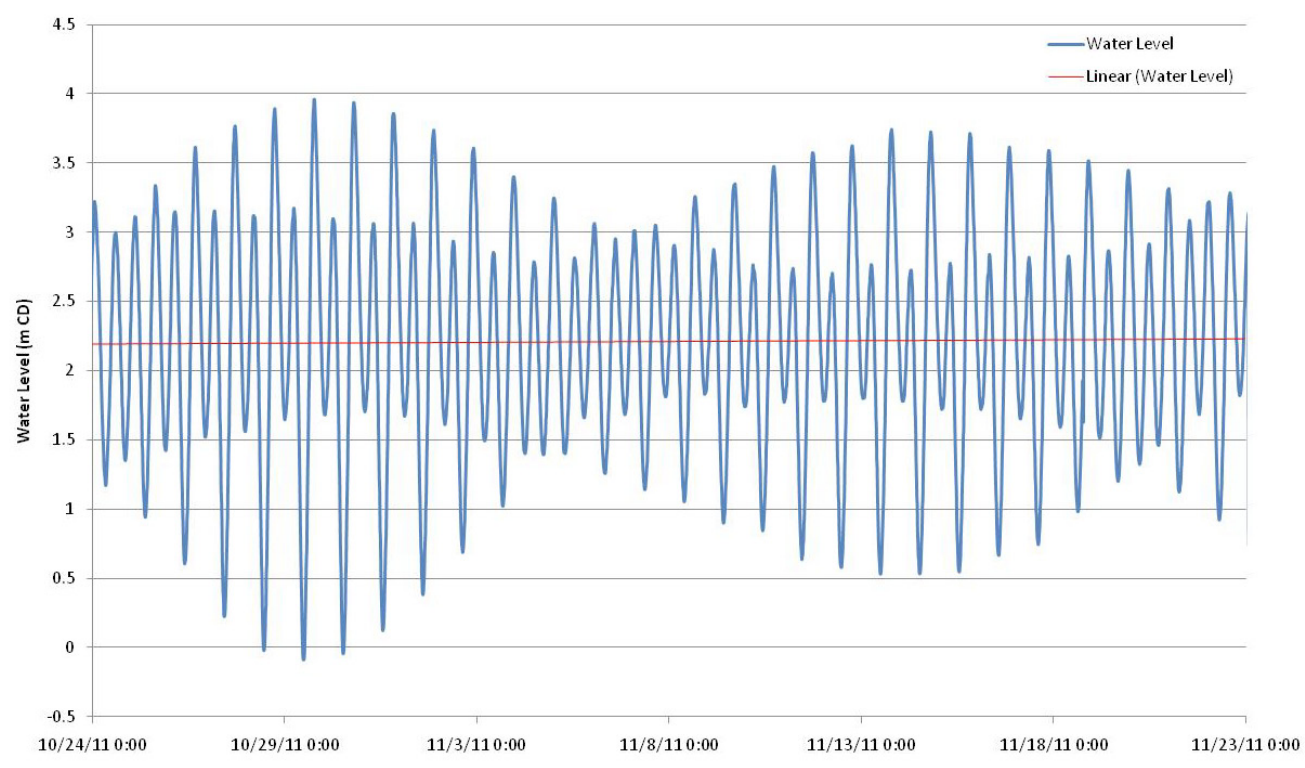

Date

Figure 3. Sea level fluctuation plotted during one month periode of measurement at Ocean Tower of Bintuni Bay.
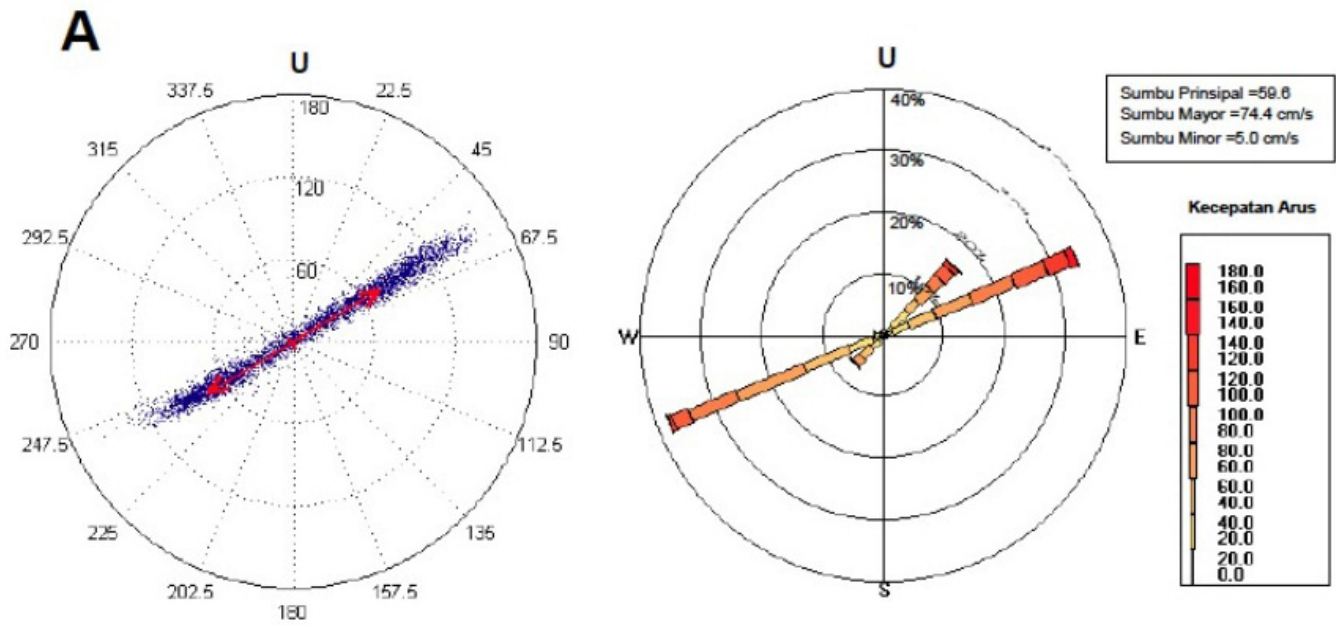

B
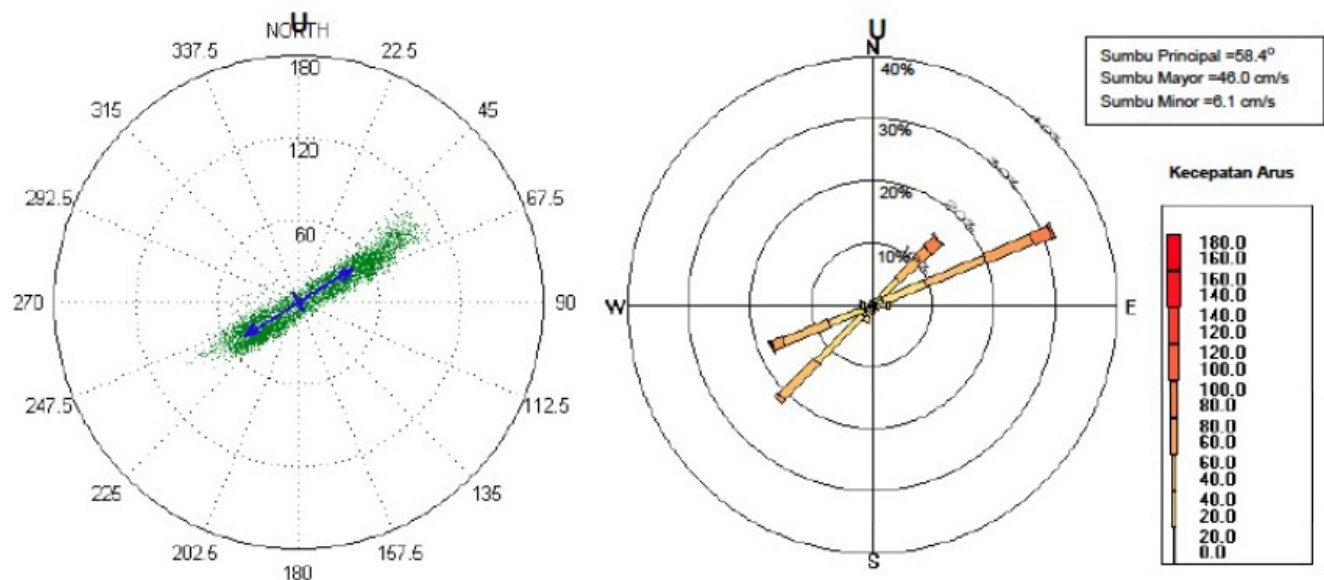

Figure 4. Current speed and current direction measured during period of December 7,1999 to March 3, 2000, A Position of CM $5.5 \mathrm{~m}$ and B position of CM $0.5 \mathrm{~m}$ onto the sea bed. 
positions, when water level at mean sea level (MSL) moves to highest level on the maximum flood, at the point of maximum flood, at the MSL moving to the lowest point of maximum ebb as well as at the point of lowest ebb.

The general pattern of water circulation within the bay on flood time is water mass flow into the bay mouth. At around of bay head mainly closed by river mouths, water mass still flows out from the river. Current speed is varied started from $5.0 \mathrm{~cm} / \mathrm{s}$ at around bay head to $100 \mathrm{~cm} / \mathrm{s}$ near the bay mouth mainly at deeper parts (Figure 5A).

At the highest water level position, water circulation pattern is described in Figure 5B. Significance changing of water circulation occurred at bay head, water mass flows into the river mouths, when the flood period strong tidal pushes water mass within bay from offshore side. Maximum current speed when water level at the highest position is $50 \mathrm{~cm} / \mathrm{s}$, at around of bay mouth current speed can reach $100 \mathrm{~cm} / \mathrm{s}$.

Current pattern when sea level position at MSL moves to the lowest ebb is deascribed in Figure $5 \mathrm{C}$. Almost all area within the bay water mass flows out from the bay into offshore ward, only mite area of the water mass still looks flow into the head of the bay.
Mean velocity of the current at the ebb period (from MSL to the lowest position) is between $5 \mathrm{~cm} / \mathrm{s}-100$ $\mathrm{cm} / \mathrm{s}$. Same as other previously position of sea level, velocity of current is looked more stronger at the part where the water depth is more deeper (indicated by dark blue color) than shallower one.

By consideration of tidal type occurred within Bintuni Bay (mixed tide prevailing semi-diurnal) so time needed of water level to move from flood peak to the lowest ebb or the other way is 6 hours. Current pattern when the position of sea level at the lowest sea level is described in Figure 5D. All along the bay and also at the around of river mouth water mass flows out seaward through the bay mouth. At the center of bay, current speed was stonger than $100 \mathrm{~cm} / \mathrm{s}$, otherwise at close to shoreline the current speed was less than $10 \mathrm{~cm} / \mathrm{s}$.

Mixing of fresh river water and the saline sea water is a fundamental physical process in estuaries (Dronkers \& van Leussen, 1988; Prandle, 2009). Figure 6 depictes spatial distribution of surface layer temperature, salinity and density On the northeast monsoon at surface layer low salinity water mass $(<25$ psu) at the head of bay closed to the river mouths is trapped by flood current flowed eastward into the Bintuni Bay (panel a) according to the pattern of tidal
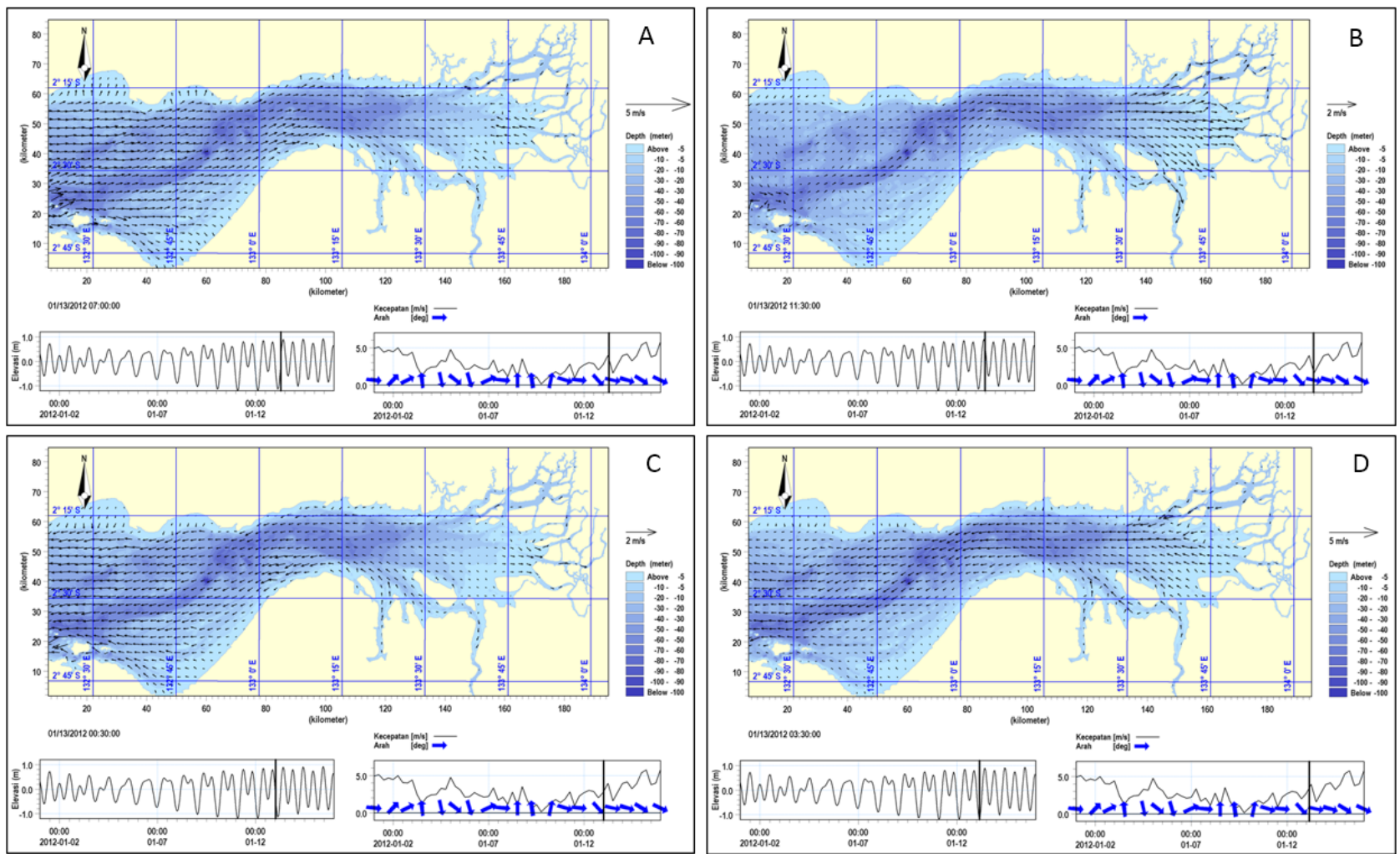

Figure 5. $\quad$ Current pattern (A) when sea level position at MSL move to the highest flood poin, (B) when sea level at the highest poin of flood, (C) when sea level at MSL poin move to the lowest poin of ebb, and (D) when the position of sea level at the lowest poin of ebb on January as representative of southeasth moonson at Bintuni Bay. 

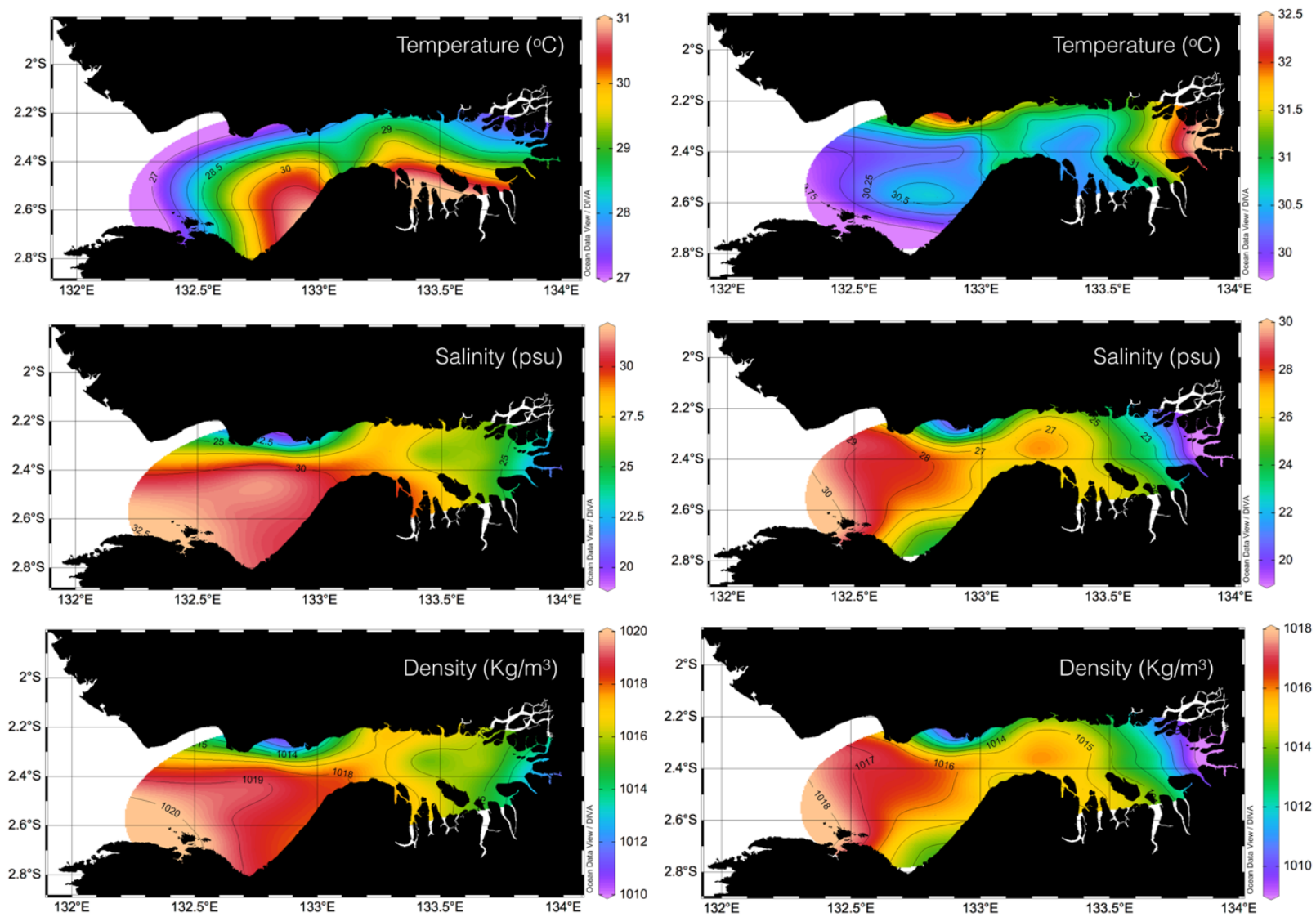

a)

b)

Figure 6. Horizontal distribution of water temperature, salinity and water density (left panel, a: northeast monsoon; right panel, b: southeast monsoon) at the Bintuni Bay.
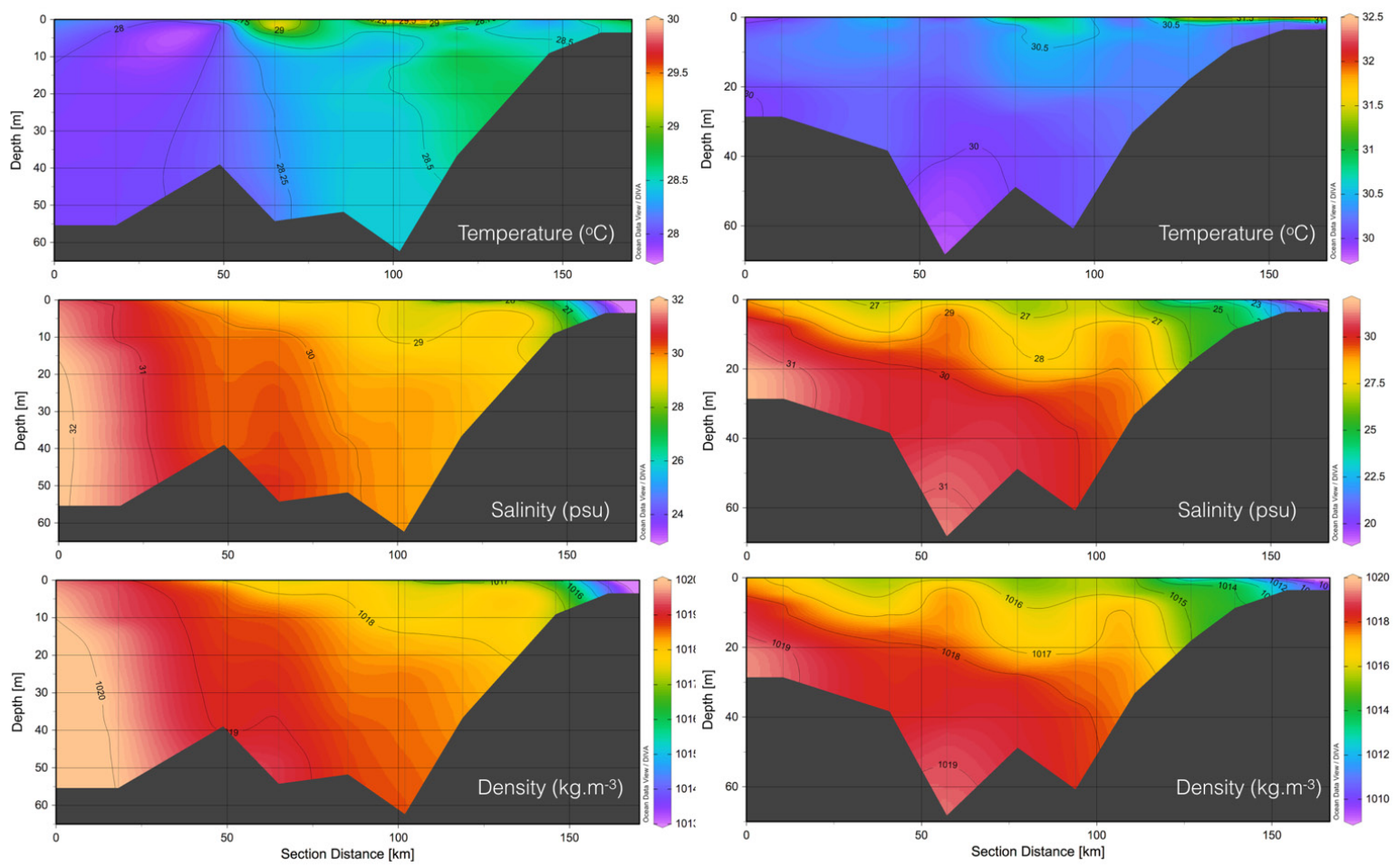

a)

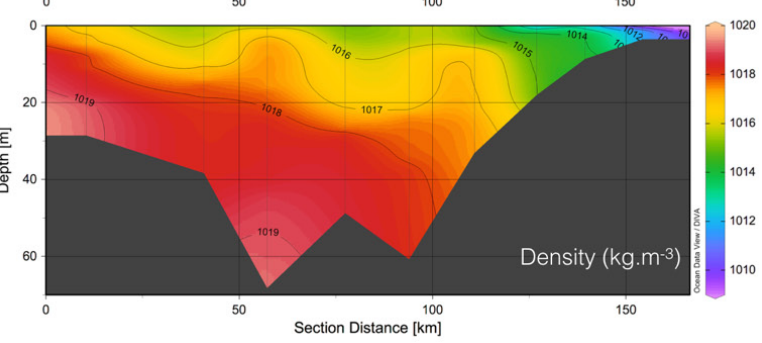

b)

Figure 7. All along the bay cross section of water temperature, salinity and water density (left panel, a: southeast monsoon, right panel, b: northeast monsoon) at the Bintuni Bay (See Fig.1). 

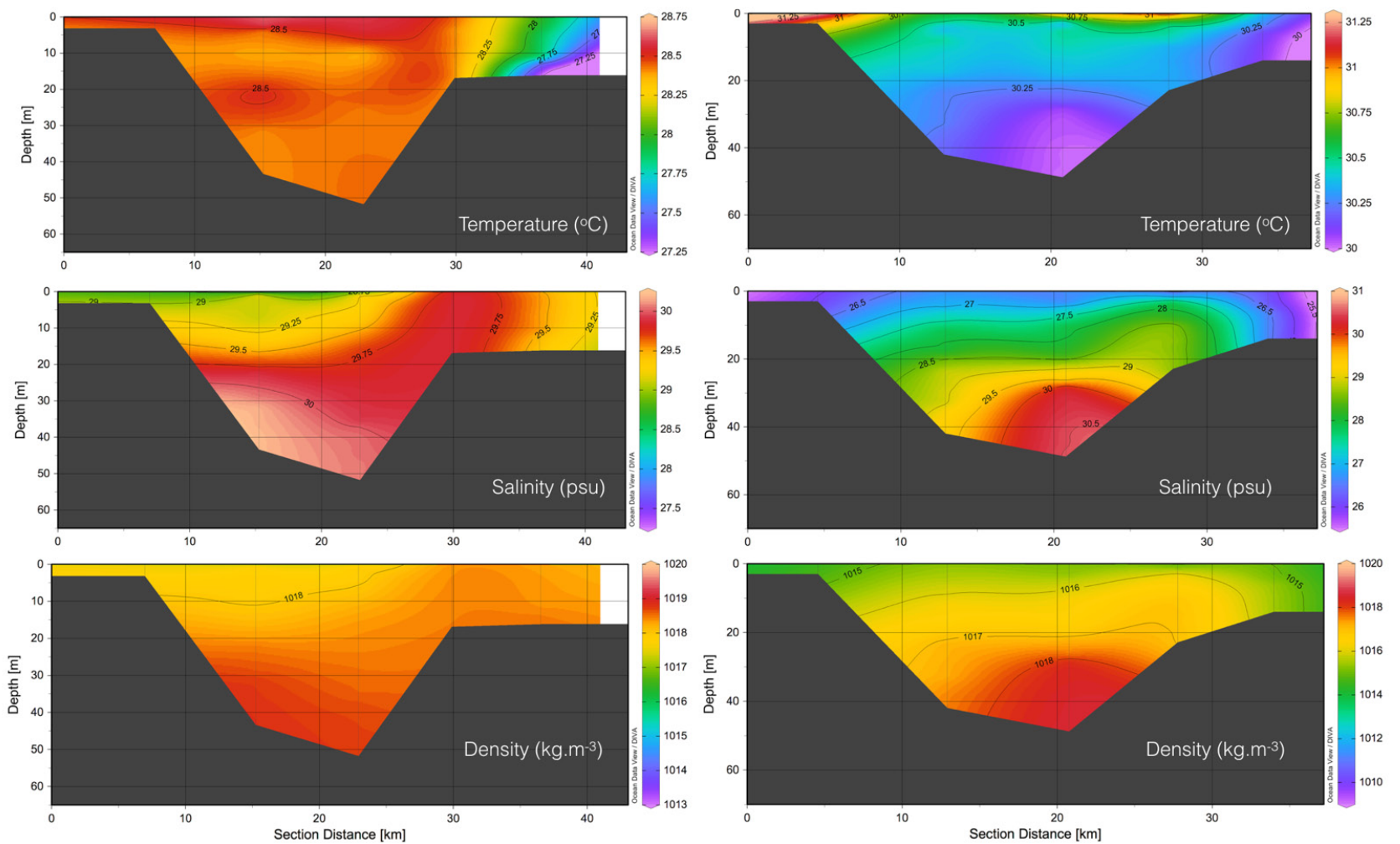

a)

b)

Figure 8. Cross shore section of water temperature, salinity and water density from northern side to southern sides of the bay (left panel, a: southeast monsoon, right panel, b: northeast monsoon) at the Bintuni Bay (See Fig. 1).

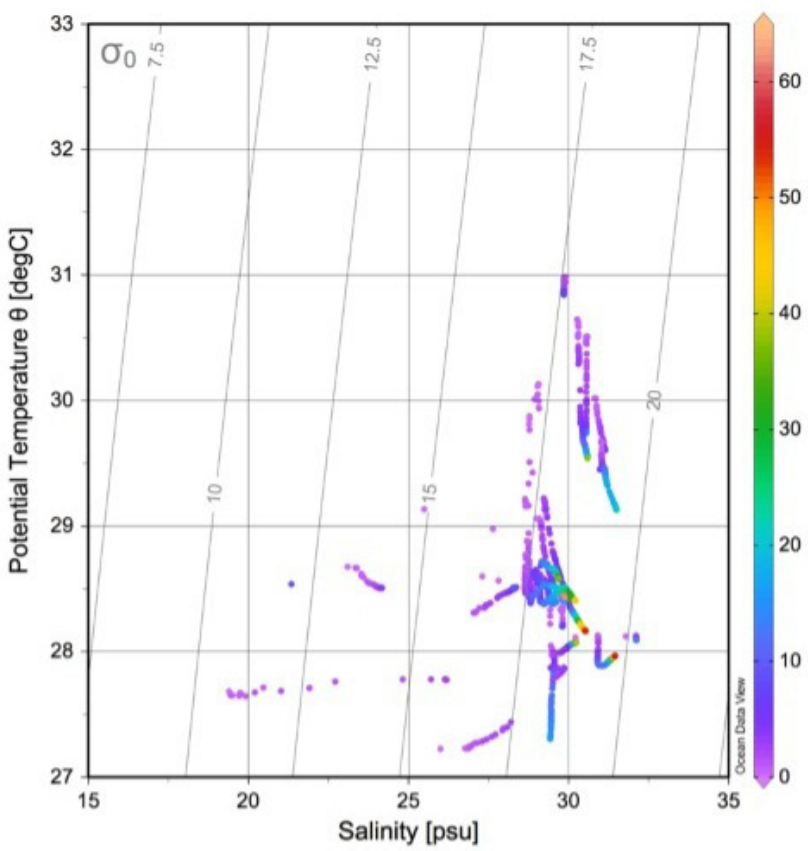

a)

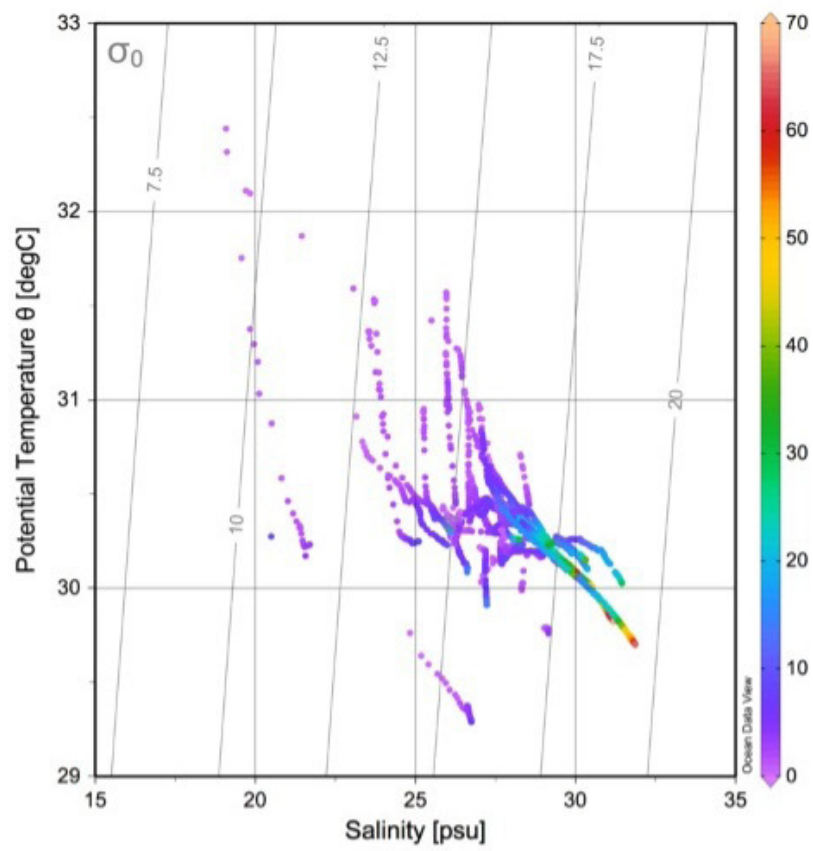

b)

Figure 9. T-S diagram (left panel, a: southeast monsoon, right panel, b: northeast monsoon) at the Bintuni Bay, color scale indicating the water depth (See Fig. 1) 
current (Figure 5).

On the other hand, at southeast monsoon low salinity water mass ( $<25 \mathrm{psu}$ ) flowed out into westward or the bay mouth direction (panel a).

To understand more detail about salinity structure within the bay, both along bay section and bay cross section are plotted (Figure 7 and Figure 8). Cross section of salinity and density along the bay are very clear, at around of bay head low salinity water is trapped. As mention previously that the isohaline of 25 psu on northeast monsoon is closer to the river mouth than the same isohaline on the southeast monsoon (indicated from green color). The same pattern was also indicated by density distribution (Figure 7).

In Figure 8 , cross section between northern and southern sides at the middle of bay shows that low salinity water mass flowed out into mouth bay direction trough northern side at the shallow water part, otherwise high salinity water flow into the bay through southern at deeper part.

There is any significance different identified from T-S diagram, on northeast monsoon low salinity water mass with high temperature $\left(>31^{\circ} \mathrm{C}\right)$ are not observed, but in southeast they are observed. In addition, several groups of water mass occured on northeast monsoon with some characteristics: low salinity and low temperature water mass group $<20.0$ psu and $<28.0^{\circ} \mathrm{C}$, high salinity water and low temperature water masses ( $>25.0$ psu and $<28{ }^{\circ} \mathrm{C}$ ), water mass with 28.0$30.0^{\circ} \mathrm{C}$ and $30.0 \mathrm{psu}$ as well as high temperature water mass and high salinity water mass $\left(>30.0^{\circ} \mathrm{C}\right.$ and $>30.0$ psu). Otherwise, on the southeast monsoon water mass is dominated by one big group water mass range between $30.0-31.5^{\circ} \mathrm{C}$ and $23.0-30.0 \mathrm{psu}$ ).

\section{CONCLUSION}

Water mass distribution within the bay of Bintuni either on northeast monsoon or southeast monsoon tends to be controlled by salinity. On the northeast monsoon water temperature ranged between 29.3 $-32.3^{\circ} \mathrm{C}$, it is higher than southeast monsoon (27.2$\left.31.0^{\circ} \mathrm{C}\right)$, for the salinity range is almost the same (18.5-32.5 psu). Low salinity water (<25.0 psu) flowed out dominantly into mouth bay direction through the nothern side of the bay where is the shallow water part, otherwise high salinity water mass (>25.0 psu) flowed into the bay through the deeper part at the southern side of the bay. On northeast monsoon observed is more assorted group of water mass than southeast monsoon.

\section{ACKOWLEDGEMENTS}

I would like to say thank BP (British Peteroleum) Tangguh Indonesia and ERM Jakarta have facilitated us during field survey.

\section{REFFERENCES}

Dronkers, J. \& W. van Leussen. (1988). Physical Processes in Estuaries. Springer-Verlag, Berlin Heidelberg. New York.

Dyer, K.R. (1973). Esturaies: A Physical Introduction. John Wiley and Sons Ltd., Great Britain.

French, P.W. (1997). Coastal and Estuarine Management. Routledge. London.

Goldberg, E.D. (1994). Coastal Zone Space: Prelude to conflict? UNESCO. Paris.

Liu, W.C., Chen, W.B., Kuo, J-T. \& Wu, C. (2008). Numerical determination of residence time and age in pastially mixed estuary using a threedimensional hydrodynamic model. Continental Shelf Research, 28 (8), 1068-1088.

Mandang, I. \& T. Yanagi. (2008). Tide and Tidal Current in Mahakam Estuary, East Kalimantan, Indonesia. Coastal Marine Science, 32(1): 1-8.

Prandle, D. (2004). How tides and river flows determine estuarine bathymetries. Progress in Oceanography, 61, 1-6.

Prandle, D. (2009). Estuaries: Dynamics, Mixing, Sedimentation and Morphology. Cambridge University Press. Cambridge.

Wolanski, E. (2007). Estuarine Ecohydrology. Elsevier. Amsterdam. ISBN. 